University of Nebraska - Lincoln

DigitalCommons@University of Nebraska - Lincoln

1999

\title{
Trace-Element Concentrations in Streambed Sediment Across the Conterminous United States
}

Karen Rice

U.S. Geological Survey

Follow this and additional works at: https://digitalcommons.unl.edu/usgsstaffpub

Part of the Earth Sciences Commons

Rice, Karen, "Trace-Element Concentrations in Streambed Sediment Across the Conterminous United States" (1999). USGS Staff -- Published Research. 56.

https://digitalcommons.unl.edu/usgsstaffpub/56

This Article is brought to you for free and open access by the US Geological Survey at DigitalCommons@University of Nebraska - Lincoln. It has been accepted for inclusion in USGS Staff -- Published Research by an authorized administrator of DigitalCommons@University of Nebraska - Lincoln. 


\section{Trace-Element Concentrations in Streambed Sediment Across the Conterminous United States}

\author{
KAREN C. RICE \\ U.S. Geological Survey, P.O. Box B, \\ Charlottesville, Virginia 22903
}

Trace-element concentrations in 541 streambed-sediment samples collected from 20 study areas across the conterminous United States were examined as part of the National Water-Quality Assessment Program of the U.S. Geological Survey. Sediment samples were sieved and the $<63-\mu \mathrm{m}$ fraction was retained for determination of total concentrations of trace elements. Aluminum, iron, titanium, and organic carbon were weakly or not at all correlated with the nine trace elements examined: arsenic, cadmium, chromium, copper, lead, mercury, nickel, selenium, and zinc. Four different methods of accounting for background/ baseline concentrations were examined; however, normalization was not required because field sieving removed most of the background differences between samples. The sum of concentrations of trace elements characteristic of urban settings - copper, mercury, lead, and zinc-was well correlated with population density, nationwide. M edian concentrations of seven trace elements (all nine examined except arsenic and selenium) were enriched in samples collected from urban settings relative to agricultural or forested settings. Forty-nine percent of the sites sampled in urban settings had concentrations of one or more trace elements that exceeded levels at which adverse biological effects could occur in aquatic biota.

\section{Introduction}

The National Water-Quality Assessment (NAWQA) program of the U.S. Geological Survey (USGS) is assessing the status of, and trends in, the surface and groundwater quality of the U.S. through its investigation of 59 study areas, called study units, nationwide (1). Investigations in study units are conducted in cycles, so that a set of 15-20 study units is in a high-intensity data-collection and interpretation phasefor 3 years, followed by 6 years of low-intensity monitoring. A specific component of the NAWQA program is to investigate concentrations of trace elements in streambed-sediment samples collected in rivers and streams in each study unit. Concentrations of 47 elements were determined in each sample; results are reported here for nine elements that are of environmental concern [arsenic (As), cadmium (Cd), chromium (Cr), copper (Cu), lead (Pb), mercury (Hg), nickel $(\mathrm{Ni})$, selenium $(\mathrm{Se})$, and zinc $(\mathrm{Zn})]$. The objectives of this paper areto (1) present data on trace-element concentrations in streambed sediments for the first set of 20 study units, which began investigations in 1991; (2) test different methods to determinebaselineconcentrations; (3) relatetrace-element

\footnotetext{
* Correspondingauthor phone: 804-297-4069; fax: 804-977-6751; e-mail: kcrice@usgs.gov.
}

10.1021/es990052s Not subject to U.S. Copyright. Publ. 1999 Am. Chem. Soc. Published on Web 06/11/1999 concentrations to population density and to land use in the sampled basin; and (4) relate trace-element concentrations to sediment-quality guidelines for effects on aquatic biota.

For most of the past century, streambed sediment was collected primarily to look for ore bodies that could be economic to mine. More recently, however, the primary interest has shifted to assessing whether trace elements are present in the environment at concentrations that are detrimental to aquatic biota or human health (2). Wood (3) classified eight of the trace elements discussed in this paper as "very toxic and relatively accessible" (chromium was not classified); all nine trace elements are on the U.S. Environmental Protection Agency's (U.S. EPA) list of 126 Priority Pollutants (4). Daskalakis and O'Conner (5) reported that data collected by the National Status and Trends (NST) Program of the National Oceanic and Atmospheric Administration showed that severe trace-element contamination is confined to small regions around densely populated coastal areas of the U.S. The U.S. EPA's Office of Science and Technology compiled sediment chemistry data collected from 1980 to 1993 from existing regional and national databases; results indicate that sediment contamination is widespread and that metals are among the contaminants most often identified (6).

Pathways by which trace elements can enter terrestrial and aquatic environments include atmospheric deposition and point and nonpoint source releases to surface water. Trace elements in the atmosphere derivefrom natural sources such as volcanic emissions and anthropogenic sources such as combustion of municipal solid waste $(7,8)$ and of fossil fuels in coal- and oil-fired power plants (7), releases from metal smelters $(9,10)$, automobile emissions $(11,12)$, and biomass burning. Point sources of trace elements include municipal sewagesludge(13), effluent to surfacewaters from coal-fired power plants (14), releases directly to water courses from industrial uses, and, in someareas, acid minedrainage. Nonpoint sources of trace elements include natural weathering of geologic materials and anthropogenic sources such as runoff of manure and artificial fertilizers from farm fields, releases from wear of automobile parts (12), and irrigation return flow (15). Industrial uses and sources include agriculture (As, Cu, Hg, Pb, Se, and $\mathrm{Zn}$ ); electrical power (As, Cd, $\mathrm{Cu}, \mathrm{Hg}, \mathrm{Pb}, \mathrm{Ni}$, Se, and $\mathrm{Zn}$ ); metallurgy (As, $\mathrm{Cd}, \mathrm{Cr}, \mathrm{Cu}, \mathrm{Hg}$, $\mathrm{Pb}, \mathrm{Ni}$, and $\mathrm{Zn}$ ); and wood and pulp (As, Cd, Cr, Cu, Hg, and $\mathrm{Pb})$.

The NAWQA program provides a comprehensive and internally consistent set of data for trace elements in streambed sediment for portions of the conterminous U.S. $(16,17)$. This paper is the first national synthesis of trace elements in streambed sediment that uses internally consistent data and is representative of upland as well as coastal areas. Other national programs have focused on estuarine/ coastal sites $(5,18)$ or have compiled data from a wide range of studies that used different sampling and analytical techniques (6). Results are presented for upstream as well as downstream sites because contaminated sediments eventually will be transported downstream to drinking-water reservoirs or coastal areas. The NAWQA Program sampling design was created to answer cause-and-effect questions (19) and differs from a stratified random sampling design [e.g., the Environmental Monitoring and Assessment Program (EMAP) of theU.S. EPA] in that random samples are collected across the frame of probability of occurrence, with more frequent sampling where probabilities are higher. 


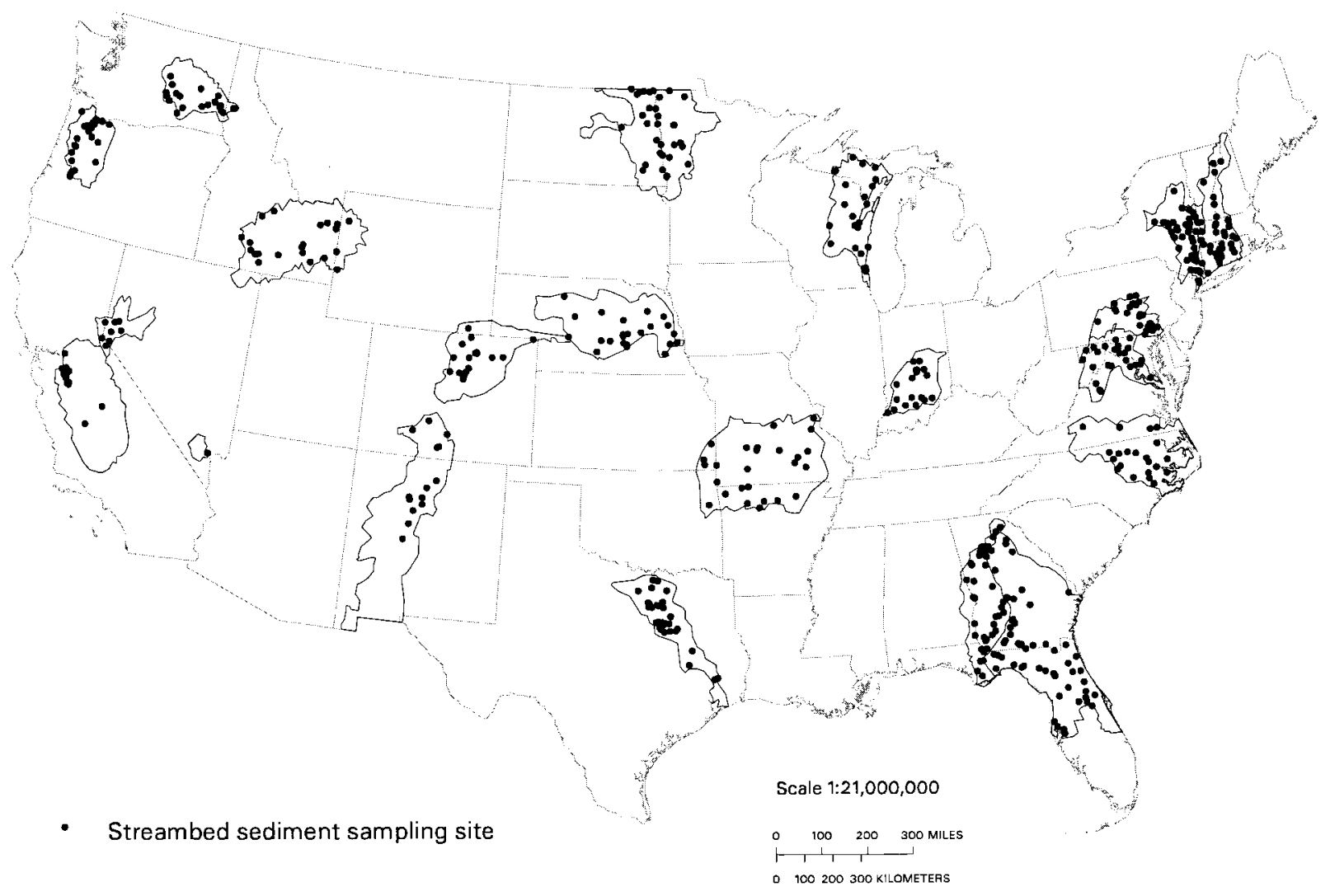

FIGURE 1. Location of 1991 NAW QA study units and 541 streambed-sampling sites sampled from 1992 to 1996.

\section{Experimental Section}

Streambed-sediment samples from the 20 study units were collected from basins with contributing areas that range in size from 1 to $221500 \mathrm{~km}^{2}$. The upper few centimeters of sediment in depositional zones were collected from 5 to 10 areas in the streambed with a plastic or Teflon scoop or a hand-coring sampler, alonga stream reach of approximately $100 \mathrm{~m}$ (20). The multiple subsamples were composited to smooth local-scale variability and to obtain a representative concentration at each sampling site (20). Trace-element concentrations are strongly dependent on grain size; in general, higher concentrations are associated with smaller grain sizes (e.g., refs 21 and 22). To increase the likelihood of detecting trace elements and to allow data among sites to be compared, the sediment samples were wet-sieved in the field using ambient water, and the $<63-\mu \mathrm{m}$ fraction (the siltand clay-fraction) was retained for analysis (23). Sediment samples were analyzed by the USGS, in Denver, CO by digesting with strong acids so that a total concentration was determined $(16,17)$, which includes concentrations of trace elements sorbed to the sediment as well as trace elements present in the mineral crystal lattice.

From 1992 through 1996, 541 streambed-sediment sites were sampled throughout the 20 study units (Figure 1). For sites where multiple samples were collected $(n=71)$, only the most recently collected sample was retained for the statistical analysis, to eliminate bias toward frequently sampled sites. For concentrations that were less than the laboratory reporting limit, one-half the minimum reporting limit for each element was substituted for the percentile calculations. Spearman's $\rho$ was used as a measure of the degree of association between trace-element concentration and population density and between trace-element concentration and land use. Spearman's $\rho$ is a nonparametric measure computed on ranked data (24), so use of one-half of the minimum reporting limit for values reported as "less than" does not bias the value of $\rho$.

Normalization of chemical concentration data to a conservative element [e.g., aluminum (Al), lithium (Li), or titanium (Ti)] is intended to eliminate variability in a traceelement data set caused by variations in rock and soil types, sedimentation rates, grain-size distribution, and diluents, such as organic carbon (21). Concentrations of conservative elements are assumed to have a uniform variability resulting from natural processes, i.e., a uniform flux from weathering of the source rock to deposition at the sampling point. Elements such as $\operatorname{Al}(25,26)$ and $\operatorname{Ti}(27,28)$ have long been used for normalization of bulk-sediment data. The strength of linear correlations between four el ements commonly used for normalization [Al, iron (Fe), Ti, and organic carbon (OC)] and the nine trace elements was evaluated.

To identify trace-element concentrations that have been affected by anthropogenic activities, data on basin characteristics upstream of the sampling site, such as population density and land use, were correlated with the trace-element concentration data to infer likely sources. Because total concentrations were determined, it was desirableto separate the concentration of trace element derived from the crystal lattice from the sorbed fraction; the latter concentration is presumed more likely to be derived from anthropogenic activities. The "background" concentration of a trace element in streambed sediment is defined as the concentration that is the result of natural processes, including weathering and subsequent erosion of local soil and bedrock, and atmospheric deposition unaffected by anthropogenic activity. Because almost every place on Earth has been affected by human activities, a more appropriate term is "baseline", which is defined as the concentration found at a particular time (e.g., the onset) during a study or monitoring program. The baseline concentration presumably has had low-level influencefrom anthropogenic activities, and theterm is used 
TABLE 1. Selected Trace- and Minor-Element Concentrations in Streambed Sediment Across Portions of the Conterminous United States, Collected from 1992 to $1996^{c}$

$\begin{array}{llc}\begin{array}{c}\text { trace } \\ \text { element } \\ (\boldsymbol{n}=\mathbf{5 4 1})^{a}\end{array} & \begin{array}{c}\text { laboratory } \\ \text { method }\end{array} & \begin{array}{c}\text { laboratory } \\ \text { minimum } \\ \text { reporting level }\end{array} \\ \begin{array}{ll}\text { arsenic } \\ \text { cadmium }\end{array} & \text { HA } & 0.01 \\ \text { chromium } & \text { GFAA } & 0.1 \\ \text { copper } & \text { ICP-AES } & 1.0 \\ \text { lead } & \text { ICP-AES } & 1.0 \\ \text { mercury } & \text { CVAA } & 4.0 \\ \text { nickel } & \text { ICP-AES } & 0.02 \\ \text { selenium } & \text { HA } & 2.0 \\ \text { zinc } & \text { ICP-AES } & 0.1 \\ \text { aluminum } & \text { ICP-AES } & 4.0 \\ \text { iron } & \text { ICP-AES } & 0.005 \\ \text { titanium } & \text { ICP-AES } & 0.005 \\ \text { OC } & \text { difference } & 0.005 \\ \end{array}$

$\begin{array}{ccc}\begin{array}{c}\text { \% samples } \\ \text { below laboratory } \\ \text { reporting level }\end{array} & \begin{array}{c}\text { min. } \\ \text { concn }\end{array} & \begin{array}{c}\text { 25th } \\ \text { percentile }\end{array} \\ 0 & 1 & 4.6 \\ 1.5 & <0.1 & 0.3 \\ 0.2 & <1.0 & 51 \\ 0 & 6 & 17 \\ 0.7 & <4.0 & 18 \\ 13.7 & <0.02 & 0.03 \\ 0 & 6 & 20 \\ 0.4 & <0.1 & 0.5 \\ 0.4 & <4.0 & 81 \\ 0 & 1.4 & 5.4 \\ 0 & 0.7 & 2.5 \\ 0 & 0.05 & 0.27 \\ 0 & 0.01 & 1.84\end{array}$

$\begin{array}{ccc}\begin{array}{c}\text { 50th } \\ \text { percentile } \\ \text { (median) }\end{array} & \begin{array}{c}\text { 75th } \\ \text { percentile }\end{array} & \begin{array}{c}\text { max. } \\ \text { concn }\end{array} \\ 6.3 & 9.2 & 200 \\ 0.4 & 0.8 & 56 \\ 64 & 84 & 700 \\ 27 & 43 & 620 \\ 27 & 44 & 6300 \\ 0.06 & 0.13 & 14.5 \\ 27 & 36 & 530 \\ 0.7 & 1.1 & 13 \\ 110 & 180 & 9000 \\ 6.4 & 7.5 & 14 \\ 3.5 & 4.5 & 19 \\ 0.36 & 0.51 & 1.9 \\ 2.76 & 4.7 & 28.7\end{array}$

a Except titanium, where $n=540$, and OC, where $n=537$, due to insufficient sample for analysis. ${ }^{b}$ Difference between total carbon and inorganic carbonate. ' Abbreviations: HA, hydride analysis; GFAA, graphite furnace atomic absorption; ICP-AES, inductively coupled plasma-atomic emission spectrometry; CVAA, cold vapor atomic absorption; OC, organic carbon; all concentrations in $\mu \mathrm{g} / \mathrm{g}$, dry weight, except aluminum, iron, titanium, and OC, which are in weight \%.

with the understanding that it represents a combination of background and other concentrations.

Several methods have been used to identify baseline concentrations of traceelements, including the use of average crustal abundance(ACA), probability plots of the distribution, and concentrations in local soils or bedrock. The most accurate method is to analyze samples of bedrock and soils collected from the sampled basin; however, these data are not generally available for most studies of streambedsediment contamination. Four methods were used to determine baselineconcentrations-ACA (29), probability plots, median concentrations in soils and surficial materials, and median concentrations of a subset of the NAWQA data.

Breaks in slope of data plotted on probability paper can be used to identify mixed populations. Assuming that "natural" samples and "perturbed" samples have different underlying distributions, probability plots can be used to identify a baseline concentration, by identifying thefirst break in slopeand recording the corresponding concentration (30). Probability plots for each of the nine elements were created for each of the 20 study units, and the break in slope was identified as the baseline threshold for each study unit.

Trace-element concentrations in soils and other surficial materials across the conterminous U .S. were obtained from Shacklette and Boerngen (31), who sampled 1318 sites at approximately $80 \mathrm{~km}$ intervals from 1958 through 1975. The $<2$-mm fraction of sample was analyzed (31). Data for each of the NAWQA study units were obtained from a digital database by querying for data located between the maximum and minimum latitude and longitude coordinates that define each study unit, which could introduce data from outside the study-unit boundaries. Concentrations of elements in the database that were not detected or that had a signal that was too weak to quantify were replaced with one-half the reporting limit of that element. Concentrations of elements that could not be quantified because of interferences were deleted; therefore, the number of analyses was not always the same for each element in each study unit. The median concentration of each element for each study unit was used as the baseline concentration.

The fourth method used to determine baseline concentrations involved the use of indicator sites, which had been designated by each NAWQA study unit as having relatively uniform and representative land use in the basin in which thesample was collected (32). Types of indicator sites include agricultural, cropland, orchards and vineyards, pasture, rangeland, forested, reference, urban, residential urban, new residential urban, commercial or industrial, and residential or commercial. Areas affected by mining were not sampled in this cycle of the NAWQA program. Because the number of referencesites was limited, a nonurban indicator sitegroup for each study unit was created by combining theagricultural site types (agricultural, cropland, orchards and vineyards, and pasture) with thereferencesitetypes (rangeland, forested, and reference). This grouping was warranted on the basis of a Mann-Whitney test comparing trace-element concentrations for each study unit, which showed that only 10 of 135 cases had significantly ( $p \leq 0.05$ ) higher concentrations in the agricultural sites than the reference sites. The median concentration of each element in the nonurban indicator site group in each study unit was used as the baseline threshold.

A "local" baseline concentration for each trace element for each study unit was determined using three methodsprobability plots, median concentrations of soils and surficial materials, and median concentrations of nonurban indicator sites. There is only one ACA for each trace element, so the same concentration was used for all of the study units. The baseline concentrations were subtracted from the total concentrations to account for contributions from local geology (background) as well as low-level anthropogenic contamination (baseline). If thesubtraction yielded a negative number, the reported and baseline concentrations were considered equivalent and a zero was substituted (Table 2 ). The resulting differences were considered to represent the quantity of metals added to the background levels for each sample by anthropogenic activities and therefore may be expected to more strongly relate to land use in the basin than "uncorrected" data. Land-use data are from the 1970s GIRAS Land Useand Land Cover 1:250 000-scalemaps, using the Level II classification scheme (33), with an update of new residential urban areas using the classification scheme and methodology of Hitt (34). Population density for each basin was obtained from the Bureau of the Census (35). Geologic information was obtained from Schruben et al. (36), and physiographic province information was obtained from Fenneman and Johnson (37).

\section{Results and Discussion}

Concentrations of $\mathrm{Pb}, \mathrm{Hg}$, and $\mathrm{Zn}$ ranged over 4 orders of magnitude, whereas concentrations of the other six trace elements ranged over 3 orders of magnitude(Table1). M edian 
TABLE 2. Baseline Concentrations of Nine Trace Elements at 541 Sampling Sites ${ }^{a, b}$

\begin{tabular}{|c|c|c|c|c|c|c|c|c|}
\hline $\begin{array}{l}\text { trace } \\
\text { element }\end{array}$ & $\mathrm{ACA}^{\mathrm{C}}$ & $\begin{array}{l}\text { ACA } \\
\%^{d}\end{array}$ & $\begin{array}{l}\text { probability } \\
\text { plots }\end{array}$ & $\begin{array}{l}\text { probability } \\
\text { plots } \% d\end{array}$ & $\begin{array}{l}\text { medians of } \\
\text { soils/surficial } \\
\text { materials }\end{array}$ & $\begin{array}{c}\text { medians of } \\
\text { soils/surficial } \\
\text { materials } \% d\end{array}$ & $\begin{array}{c}\text { medians of } \\
\text { nonurban } \\
\text { indicator sites }\end{array}$ & $\begin{array}{c}\text { medians of } \\
\text { nonurban } \\
\text { indicator } \\
\text { sites \% }\end{array}$ \\
\hline arsenic & 1.8 & 2 & $2.2-21$ & 29 & $2-9$ & 32 & $4.8-21$ & 52 \\
\hline cadmium & 0.15 & 7 & $0.1-0.5$ & 32 & & & $0.075-0.8$ & 53 \\
\hline chromium & 102 & 87 & $20-100$ & 36 & $15-85$ & 14 & $45.5-105$ & 50 \\
\hline copper & 60 & 86 & $10-53$ & 37 & $5-70$ & 25 & $13-47$ & 46 \\
\hline lead & 14 & 16 & $9-35$ & 29 & $5-30$ & 20 & $11-56.5$ & 49 \\
\hline mercury & 0.085 & 61 & $0.01-0.08$ & 29 & $0.02-0.18$ & 50 & $0.01-0.26$ & 50 \\
\hline nickel & 84 & 97 & $12-51$ & 30 & $5-30$ & 9 & $16-66$ & 50 \\
\hline selenium & 0.05 & 0 & $0.2-1.0$ & 32 & $0.12-0.51$ & 14 & $0.3-1.2$ & 56 \\
\hline zinc & 70 & 16 & $33-140$ & 26 & $20-79$ & 4 & $68.5-240$ & 47 \\
\hline
\end{tabular}

${ }^{a}$ Concentrations were determined for each of the 20 NAWQA study units using probability plots, median concentrations of soils and surficial materials, and median concentrations of nonurban indicator sites; the range in concentration for each trace element from the set of 20 study units is reported. ${ }^{b}$ All concentrations in $\mu \mathrm{g} / \mathrm{g}$, dry weight. ${ }^{c}$ Average crustal abundance (29). ${ }^{d}$ Indicates the percent of 541 samples that was $\leq 0$ after the baseline concentration was subtracted from the total concentration.

concentrations of $\mathrm{As}, \mathrm{Cd}, \mathrm{Pb}$, Se, and $\mathrm{Zn}$ (Table 1) exceeded ACA (Table 2), and maximum concentrations of all nine elements exceeded ACA by 6-fold ( $\mathrm{Ni}$ ) to 450-fold ( $\mathrm{Pb}$ ). These results suggest that human activity has resulted in higher environmental trace-element concentrations than those contributed by natural weathering of geologic materials.

For the nonurban indicator site group ( $n=450$ ), coefficients of determination $\left(r^{2}\right)$ between four normalizing elements ( $\mathrm{Al}, \mathrm{Fe}, \mathrm{Ti}$, and $\mathrm{OC}$ ) and the nine trace elements ranged from 0.00 to 0.27 (Fe and $\mathrm{Ni}$ ). Of the $4 \times 9$ matrix, 31 of the $r^{2}$ values were 0.05 or less, and 12 of the $r^{2}$ values were 0.00 . These results indicate that the common normalizing elements do not correlate with the other trace-element concentrations in this data set and contrast with resultsfrom EMAP (18) and the NST program (5). EMAP, however, used bulk sediments, and NST used bulk sediments mathematically corrected to $<64 \mu \mathrm{m}$; sample sites for both of these national programs were confined to coastal and estuarine watersheds. In contrast, NAWQA sampled sites across the country, which represent a much broader range of lithologies and field sieved samples to $<63 \mu \mathrm{m}$. The resulting silts and clays are more homogeneous in composition than is a bulk sample, decreasing the likelihood of covariation of trace elements with normalizing elements.

Identifying the "break in slope" of the distribution on the probability plots was arbitrary. According to Velz (30), a combined data set of samplesfrom polluted and nonpolluted sources plotted on probability paper yields "two (or more) quite different lines, with a sharp break-point separating the polluted values from those of natural background". The probability plots for each metal for each study unit typically did not show a "sharp break-point". Multiple breaks in slope were problematic, because it was impossible to determine which break represented baseline. For consistency, the arbitrary decision was made to use the second "stair step" or break in slope from the low end of the curve.

Baseline concentrations are subtracted from total concentration data with the expectation that adjusted data will have better correlations with land use in the sampled basin. This occurred rarely (five correlations) and with minor significance (improvements in $\rho$ 's of $0.01-0.13$ ) with the four methods described (Table 3 ), despite the wide range in baseline concentrations among the four methods (Table 2). It appears that the sieving procedure provided normalization for this data set, because adjusting for baseline with any of the methods improved very few of the correlations of traceelement concentration with land use or population density. Based on these results, the remainder of the discussion focuses on the unadjusted data.

Despite the low number of urban indicator sites sampled nationwide (17\%), there is good correlation of thesum of the
TABLE 3. Spearman's $\rho$ Values for Nine Trace Elements and Two Types of Land Use and Population Density, Using Four Methods of Accounting for Baseline Concentrations

\begin{tabular}{|c|c|c|c|c|c|}
\hline $\begin{array}{l}\text { land use or } \\
\text { population } \\
\text { density }\end{array}$ & $\begin{array}{c}\text { original } \\
\text { data }\end{array}$ & ACA & $\begin{array}{c}\text { probability } \\
\text { plots }\end{array}$ & $\begin{array}{c}\text { medians } \\
\text { of soils/ } \\
\text { surficial } \\
\text { materials }\end{array}$ & $\begin{array}{c}\text { medians of } \\
\text { nonurban } \\
\text { indicator } \\
\text { sites }\end{array}$ \\
\hline \multicolumn{6}{|c|}{ Arsenic } \\
\hline orchard/vineyards & & $a$ & $a$ & a & $a$ \\
\hline deciduous forest & 0.15 & 0.15 & $a$ & 0.14 & $a$ \\
\hline population density & a & a & $a$ & $a$ & $a$ \\
\hline \multicolumn{6}{|c|}{ Cadmium } \\
\hline orchard/vineyards & a & a & 0.13 & & $a$ \\
\hline deciduous forest & 0.25 & 0.25 & 0.14 & & 0.11 \\
\hline population density & 0.25 & 0.25 & 0.27 & & 0.24 \\
\hline \multicolumn{6}{|c|}{ Chromium } \\
\hline orchard/vineyards & 0.32 & 0.26 & 0.20 & 0.32 & 0.16 \\
\hline deciduous forest & 0.12 & $a$ & $a$ & 0.12 & $a$ \\
\hline population density & 0.33 & 0.20 & $a$ & 0.33 & 0.12 \\
\hline \multicolumn{6}{|c|}{ Copper } \\
\hline orchard/vineyards & 0.13 & a & $a$ & 0.14 & $a$ \\
\hline deciduous forest & 0.15 & 0.11 & a & 0.14 & a \\
\hline population density & 0.49 & 0.29 & 0.27 & 0.49 & 0.40 \\
\hline \multicolumn{6}{|c|}{ Lead } \\
\hline orchard/vineyards & 0.24 & 0.24 & 0.14 & 0.23 & $a$ \\
\hline deciduous forest & 0.29 & 0.28 & 0.17 & 0.28 & 0.13 \\
\hline population density & 0.61 & 0.61 & 0.48 & 0.61 & 0.45 \\
\hline \multicolumn{6}{|c|}{ Mercury } \\
\hline orchard/vineyards & 0.31 & 0.24 & 0.20 & 0.29 & 0.19 \\
\hline deciduous forest & 0.15 & $a$ & 0.12 & 0.12 & $a$ \\
\hline population density & 0.46 & 0.38 & 0.38 & 0.43 & 0.29 \\
\hline \multicolumn{6}{|c|}{ Nickel } \\
\hline orchard/vineyards & 0.17 & $a$ & 0.14 & 0.17 & $a$ \\
\hline deciduous forest & 0.33 & 0.12 & 0.15 & 0.34 & 0.11 \\
\hline population density & 0.32 & a & 0.15 & 0.32 & a \\
\hline \multicolumn{6}{|c|}{ Selenium } \\
\hline orchard/vineyards & 0.13 & 0.13 & 0.14 & 0.13 & $a$ \\
\hline deciduous forest & 0.12 & 0.12 & a & 0.12 & $a$ \\
\hline population density & a & a & $a$ & a & $a$ \\
\hline \multicolumn{6}{|c|}{ Zinc } \\
\hline orchard/vineyards & 0.12 & 0.12 & a & 0.12 & $a$ \\
\hline deciduous forest & 0.27 & 0.27 & 0.17 & 0.27 & $a$ \\
\hline population density & 0.49 & 0.50 & 0.41 & 0.49 & 0.39 \\
\hline Not significant ( & $>0.10$ & & & & \\
\hline
\end{tabular}

concentrations of four trace elements $(\mathrm{Cu}+\mathrm{Hg}+\mathrm{Pb}+\mathrm{Zn})$ with population density (Figure 2). Each of the four individual plots looks similar to the plot of the sum of the four trace elements. Population density can be used as a surrogate for automobile density in urban and suburban areas (38), and automobiles may be an important source of $\mathrm{Cu}, \mathrm{Pb}$, and $\mathrm{Zn}$ 


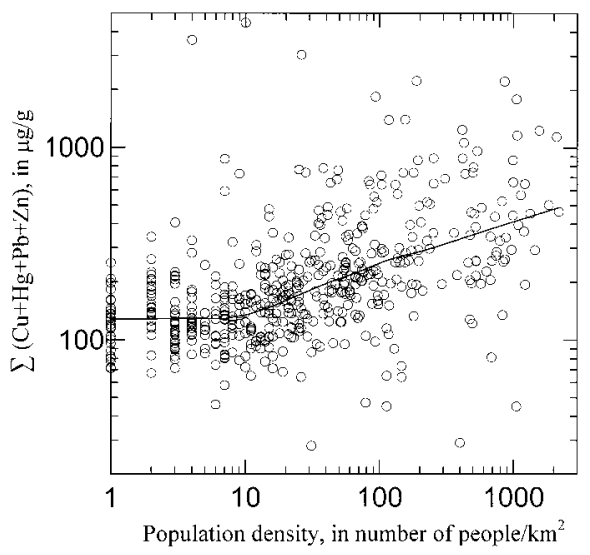

FIGURE 2. Log-log plot of population density (in number of people per $\mathrm{km}^{2}$ ) vs sum of concentrations of urban trace elements $(\mathrm{Cu}+$ $\mathrm{Hg}+\mathrm{Pb}+\mathrm{Zn}$ ). Spearman's $\rho=0.54 ; n=539$ (tw o outliers were excluded). Line draw $n$ by LOWESS smoother (24).

(12). Population density can also be used as a surrogate for total urban land use (i.e., the sum of the percentages of the fivetypes of urban land use in each basin) $\left(r^{2}=0.88, n=541\right.$, $\mathrm{p}=0.00$ )

Although the $\rho$ value for the plot of population density and the sum of concentrations $(\mathrm{Cu}+\mathrm{Hg}+\mathrm{Pb}+\mathrm{Zn})$ is good for a national data set, some unexplained variability remains. $\rho$ values for the 20 individual study units for the sum of the four trace elements and population density range from 0.00 to 0.80 . In general, study units in which most of the sample sites are associated with low population densities have the lowest $\rho$ values. The $\rho$ value for the sum of the four trace elements and population density for sites sampled in the Coastal Plain physiographic province $(\rho=0.31 ; n=103)$ was significantly less than the $\rho$ for all sites combined $(\rho=0.54)$. Similarly, the variability could not be explained by general rock type. The three groups-metamorphic, igneous, and sedimentary-had $\rho$ values for the sum of the four trace elements and population density of $0.46,0.41$, and 0.51 , respectively.

Median concentrations of the two groups of indicator sites-the nonurban indicator site group $(n=450)$ and the urban indicator site group $(n=91)$-are clearly different for seven of thetraceelements (Figure 3). A Mann-Whitney test for significance confirmed thatall of the traceelements except As and Se in the nonurban indicator site group were significantly different $(p=0.00)$ than the urban indicator site group. (The urban indicator site group includes all indicator sites designated as urban by study-unit personnel as well as a few sites with mixed land use but with urban land use the highest percentage). Only As and Se did not have a differencein median concentration between thetwo groups, and $\mathrm{Ni}$ showed less of a difference than any of the other six trace elements (Figure 3). The large differences in the six trace elements can be attributed to the high potential for releases from point and nonpoint sources from both industrial and residential uses typical of urban areas. O'Brien (39) found that concentrations of $\mathrm{As}$ and $\mathrm{Ni}$ in streambedsediment samples in New Jersey do not vary consistently with land use but that $\mathrm{Cu}, \mathrm{Pb}$, and $\mathrm{Zn}$ are related to basin population.

Determining that sites with urban land use have higher concentrations than baseline does not answer the question "Are these concentrations high enough to be harmful to aquatic biota?". The Canadian Sediment Quality Guidelines (SQG) (40) provide two benchmarks for that purpose, a threshold effect level (TEL) and a probable effect level (PEL). According to the SQG, bulk-sediment concentrations below the TEL rarely provoke adverse biological effects, whereas
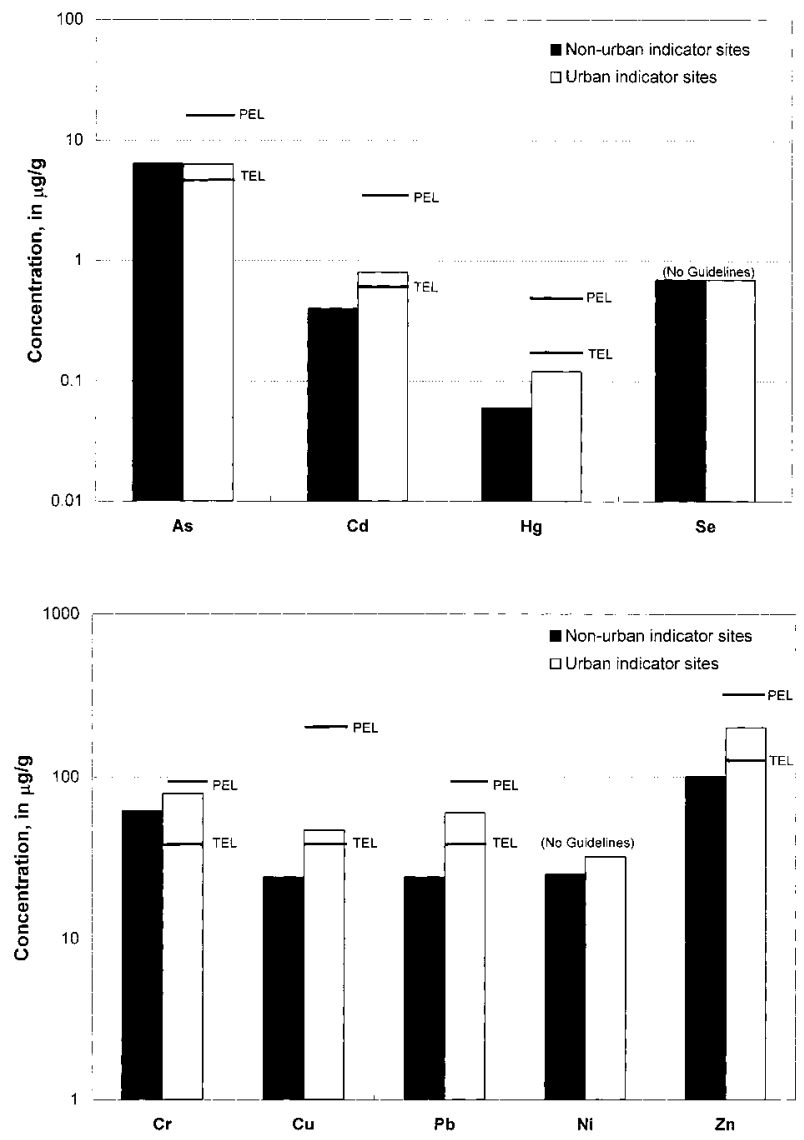

FIGURE 3. Median concentrations of nine trace elements collected from nonurban and urban indic ator sites and comparison to Canadian Sediment Quality Guidelines (SQG) (40). Threshold Effect Level (TEL) and Probable Effect Level (PEL) concentrations are show $n$.

bulk-sediment concentrations between the TEL and PEL occasionally provoke adverse effects, and concentrations abovethePEL frequently provokethose effects. NAWQA data are compared to the freshwater SQG with the understanding that concentrations for the sieved samples will be higher than those in bulk sediments of the stream [e.g., Zn concentration of $110 \mu \mathrm{g} / \mathrm{g}$ in a bulk-sediment sample that consists of $80 \%<63 \mu \mathrm{m}$ and $20 \%>63 \mu \mathrm{m}$ will be $138 \mu \mathrm{g} / \mathrm{g}$ in the $<63-\mu \mathrm{m}$ fraction (21)]. Trace-element concentrations in the silt- and clay-fraction resulting from sieving, however, should be similar to those in sediments deposited downstream of thesamplinglocations in slack-water environments critical to biota, such as in stream-channel pools and reservoirs.

The median concentration of the urban indicator site group for six of the trace el ements exceeded the TEL but not the PEL (thereare no SQ G for Ni or Se) (Figure 3). The median $\mathrm{Hg}$ concentration of either group did not exceed the TEL (Figure 3). Concentrations of one or more of the seven trace elements with SQG exceeded the PEL at 45 of the 91 urban indicator sites (49\%) and at 176 of the 541 sites overall (33\%). No samples exceeded the PEL for any trace elements at any sites in two study units, the Central Columbia Plateau in Washington and northwestern Idaho $(n=20)$ and the Central Nebraska Basin $(n=23)$.

At the national scale, the sieving procedure provided normalization for this data set, making adjustments for baseline concentrations unnecessary. Good correlation between the sum of four trace elements $(\mathrm{Cu}+\mathrm{Hg}+\mathrm{Pb}+$ $\mathrm{Zn}$ ) and population density at the national scale was found, but additional variability in the data set could not be explained with the physical parameters available. Median concentra- 
tions of $\mathrm{Cd}, \mathrm{Cr}, \mathrm{Cu}, \mathrm{Pb}, \mathrm{Hg}, \mathrm{Ni}$, and $\mathrm{Zn}$ in areas with urban land use were higher than in nonurban areas across the U.S. Streambed-sediment samplescollected in two predominantly rural areas (eastern Washington and central Nebraska) were relatively free of trace-element contamination and had concentrations similar to baseline. Samplingsites with traceelement concentrations that exceeded the level at which adverse effects to aquatic biota are expected to occur frequently were widespread, particularly in urban areas.

\section{Acknowledgments}

This research was supported by the USGS NAWQA Program. Thanks goes to C. Alpers, E. Callender, F. Rinella, and two anonymous reviewers for helpful comments. The author gratefullyacknowledges D. Helsel for guidance and B. Ruddy and R. Sanzolone for technical support. Any use of trade, product, or firm names is for descriptive purposes only and does not constitute endorsement by the USGS.

\section{Literature Cited}

(1) Hirsch, R. M.; Alley, W. M.; Wilber, W. G. U.S. Geol. Surv. Circ. 1988, 1021.

(2) Foster, I. D. L.; Charlesworth, S. M. Hydrol. Processes 1996, 10, 227.

(3) Wood, J. M. Science 1974, 183, 1049.

(4) Water qualitystandardshandbook, 2nd ed.; EPA-823-B-94-005b; U.S. Environmental Protection Agency: 1994; Appendix P.

(5) Daskalakis, K. D.; O'Conner, T. P. Environ. Sci. Technol. 1995, 29(2), 470.

(6) Theincidenceand severity of sediment contamination in surface waters of theUnited States, 1 National Sediment Quality Survey; EPA-823-R-97-006; U.S. Environmental Protection Agency: 1997.

(7) Campbell, W. J. Environ. Sci. Technol. 1976, 10, 436.

(8) Germani, M. S.; Zoller, W. H. Atmos. Environ. 1994, 28(8), 1393.

(9) Crecelius, E. A.; Bothner, M. H.; Carpenter, R. Environ. Sci. Technol. 1975, 9(4), 325.

(10) Ragaini, R. C.; Ralston, H. R.; Roberts, N. Environ. Sci. Technol. 1977, 11(8), 773.

(11) Ondov, J. M.; Zoller, W. H.; Gordon, G. E. Environ. Sci. Technol. 1982, 16(6), 318

(12) Shaheen, D. G. 600/2-75-04; U.S. EPA: 1975.

(13) Furr, A. K.; Lawrence, A. W.; Tong, S. S. C.; Grandolfo, M. C.; Hofstader, R. A.; Bache, C. A.; Gutenmann, W. H.; Lisk, D. J. Environ. Sci. Technol. 1976, 10, 683.

(14) Dreesen, D. R.; Gladney, E. S.; Owens, J. W.; Perkins, B. L.; Wienke, C. L.; Wangen, L. E. Environ. Sci. Technol. 1977, 11(10), 1017.

(15) Stephens, D. W.; Waddell, B.; Peltz, L. A.; Miller, J. B. U.S. Geol. Surv. Water-Resour. Invest. 1992, 92-4084.
(16) U.S. Geol. Surv. Open-File Report 1990, 90-668.

(17) U.S. Geol. Surv. Open-File Report 1996, 96-525.

(18) Summers, J. K.; Wade, T. L.; Engle, V. D.; Malaeb, Z. A. Estuaries 1996, 19(3), 581.

(19) Helsel, D. R. Proc. Biometrics Sect. Am. Statistical Assoc. 1995, 60-67.

(20) Shelton, L. R.; Capel, P. D. U.S. Geol. Surv. Open-File Report 1994, 94-458.

(21) Horowitz, A. J. A primer on sediment-trace element chemistry, 2nd ed.; Lewis Publishers: Chelsea, MI, 1991.

(22) Salomons, W.; Förstner, U. Metals in the hydrocycle; SpringerVerlag: New York, 1984.

(23) Helsel, D. R.; Koltun, G. F. U.S. Geol. Surv. Water-Supply Paper 1986, 2310.

(24) Helsel, D. R.; Hirsch, R. M. Statistical methodsin water resources Elsevier: New York, 1992.

(25) Piper, D. Earth Planet. Sci. Lett. 1973, 19, 75.

(26) Bruland, K.; Bertine, K.; Koide, M.; Goldberg, E. Environ. Sci. Technol. 1974, 8, 425.

(27) Forstner, U.; Wittmann, G. Metal pollution in the aquatic environment, 2nd revised ed.; Springer-Verlag: New York, 1981.

(28) Horowitz, A. J.; Elrick, K.; Callender, E. Chem. Geol. 1988, 67 17.

(29) CRC handbook of chemistry and physics, 78th ed.; Lide, D. R., Ed.; CRC Press: Boca Raton, FL, 1997.

(30) Velz, C. L. Applied stream sanitation, 2nd ed.; John Wiley: New York, 1984.

(31) Shacklette, H. T.; Boerngen, J. G. U.S. Geol. Surv. Professional Paper 1984, 1270.

(32) Gilliom, R. J.; Alley, W. M.; Gurtz, M. E. U.S. Geol. Surv. OpenFile Report 1995, 94-314.

(33) Anderson, J. R.; Hardy, E. E.; Roach, J. T.; Witmer, R. E. U.S. Geol. Surv. Professional Paper 1976, 984.

(34) Hitt, K. J. U.S. Geol. Surv. Water-Resour. Invest. 1994, 94-4250.

(35) Bureau of the Census, Public Law 94-171 data (United States) [machine-readable files]; Washington, D.C., The Bureau, 1991.

(36) Schruben, P. G.; Arndt, R. E.; Bawiec, W. J. Geology of the conterminous United States at 1:2 500 000-scale (CD-ROM).

(37) Fenneman, N. M.; Johnson, D. W. U.S. Geol. Surv. 1946

(38) Callender, E.; Van Metre, P. C. Environ. Sci. Technol. 1997, 31(9), 424A.

(39) O'Brien, A. K. J. Am. Water Resour. Assoc. 1997, 33(2), 387.

(40) Canadian environmental quality guidelines; Canadian Council of Ministers of the Environment: Winnipeg, 1998.

Received for review January 19, 1999. Revised manuscript received May 6, 1999. Accepted May 12, 1999.

ES990052S 